\title{
香気成分と質量分析
}

\section{Analysis of Aroma Components and Mass Spectrometry}

\author{
矢口善博 \\ Yoshihiro YAGUCHI \\ 高砂香料工業株式会社研究開発本部 Corporate Research \& Development Division, Takasago International \\ Corporation
}

（Received December 4, 2017; Accepted December 11, 2017）

\section{1.はじめに}

私たちの身の回りには多くの香りがあふれています。才 レンジやイチゴ，パッションフルーツといった果実の瑞々 しい香り，焼き菓子は甘くて香ばしい香り，バラの優雅な 香り，また，賦香品ではシャンプーやオーデコロンは華や かな香り, 香りは私たちの生活に密着し気持ちを豊かにし てくれます。これらの香りはヒトがその嗅覚で感じ取って いますが，香りの本体は香質や香気強度の異なる数百から 千にも及ぶ有機化合物からなっています。香料会社では分 析者がこれら成分を明らかにし，パフューマーやフレーバ リストといった調香師がその情報をもとに創香し調合しま す. 香気成分の分析は質量分析法, 特にガスクロマトグラ フィ一質量分析法（GC/MS）の登場以降それが不動の地位 を占めています．本稿では香気成分物質の分析と質量分析 という観点からいくつかのトピックスを紹介していきます.

\section{2. 香りの分子}

香りを構成する化合物は分子量 300 程度までの比較的小 さな有機分子です，構成元素は主に炭素 $(\mathrm{C})$, 水素 $(\mathrm{H})$, 酸素 $(\mathrm{O})$, 窒素 $(\mathrm{N})$, 硫黄 $(\mathrm{S})$, 塩素 $(\mathrm{Cl})$ などからな ります。多くのものは脂溶性のオイル状であり水には溶解 しにくいのが特徵です。 また, 適度な揮発性・拡散性を持 ち，容易に空中に漂うのでヒトが鼻で香気成分物質を捕え 香りとして認知します。台所で調理している食事の香りを 別の部屋で嗅いで今日の献立がわかったり, 何軒も先の焙 煎コーヒー店の香りを感じるのもこれら分子が空中を漂っ て私たちの鼻に到達するためです。これらの香気成分は図 1 に示すようにその炭素骨格や酸化様式により実にバラエ ティ豊かな種類を有します．テルペン類は植物の二次代謝 産物として知られ，多種多様な化合物群により多種多様な 香気を提供してくれます。ポリケチドやアミノ酸を由来と

連絡先：yoshihiro_yaguchi@takasago.com
する芳香族化合物類はバラの香りを有する 2-phenylethanol やシナモン用香気を有する cinnamaldehydeなどが，また， 糖類の分解物であるフラン, ピラン類では 4-hydroxy-2,5dimethyl-3 (2H)-furanone（商品名：furaneol）や maltol と いった甘い香りを有する化合物が見られます。脂質を由来 とする直鎖脂肪族アルコール，アルデヒド，酸，エステル などはさまざまな果実中に見られます。一般に何ら官能基 を持たない炭化水素は特徵的な香質を持たず，二重結合や アルコール，カルボニル，酸，エステルといった酸素官能 基が存在すると特徵的な香質を有するようになります。ピ ラジン類やチオール，スルフィド類といった窒素や硫黄が 分子内に含まれる化合物はスープやシチューといった肉や 野菜の調理食品の香りでは欠かすことのできない非常に重 要なプレーヤーです。しかしながら，それら化合物の濃度 が高いと獣臭や腐敗・翼尿臭といった特徵が表れてきま す.さらには，化合物の幾何異性や位置異性，鏡像異性に よって香りの質が異なることがあります ${ }^{1) 〜 3) . ~}$

これら化合物にはそれぞれの香り存在を認識できる最低 濃度（匂い閾值）が存在します。表 1 に示すようにこの閾 值は化合物ごとに異なる值を持ち ${ }^{4)}$, 極めて低濃度で認識 できる化合物もあれば，ある程度高い濃度がないと認識で きない化合物があります。

\section{3. 香りを分析するということ}

われわれの研究テーマの一つに「香気成分分析」があり ます。これまでに旬の果物の香り，さまざまな食品の香 り，さらには小笠原諸島や礼文島といった離島の希少な花 の香り ${ }^{5,6)}$ をターゲットに成分分析を実施し，香料を調香 するための情報として分析結果を蓄積してきました。「香 りの成分を分析する」とはおおまかに次の三つのステップ を実施します。まず，香りを捕まえること．次いで捕まえ た香りの成分を機器分析（GC/MSなど）に供すること. 最後に得られたデータを解析し含まれる成分とその量を明 らかにすることです，香りを捕集する技術もさまざまな種 


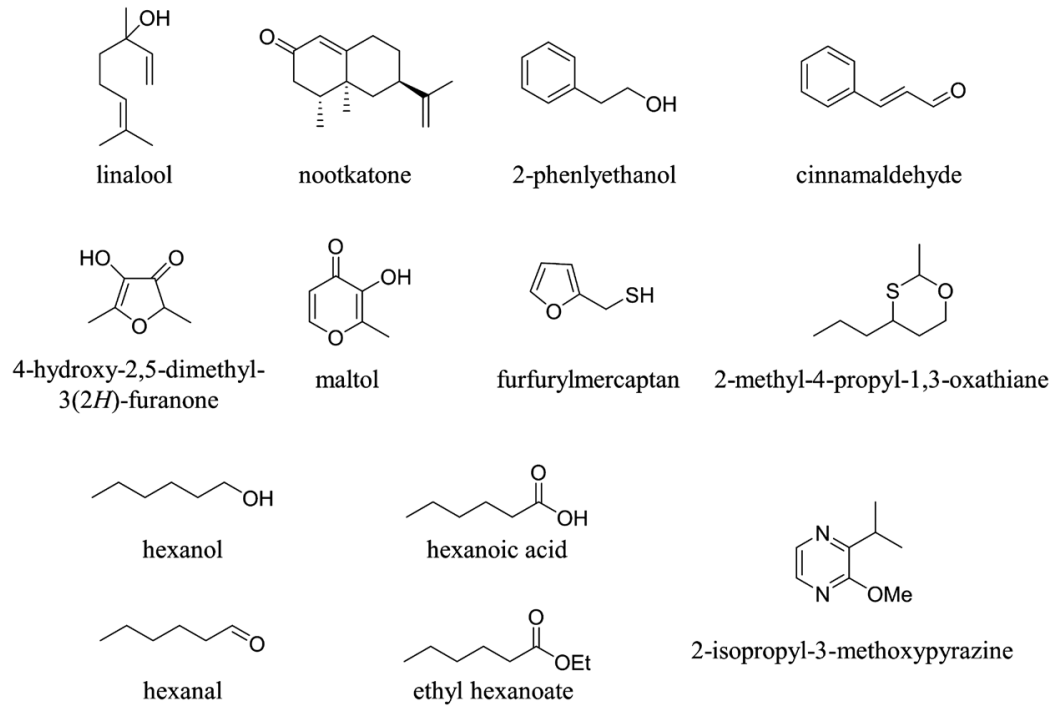

図1. 香気成分物質の例.

表1. 香気成分物質の匂い閾值（空気中）の例 ${ }^{4}$

\begin{tabular}{lc}
\hline \multicolumn{1}{c}{ 化合物 } & 閾值 $(\mathrm{ppb})$ \\
\hline Ethanol & 520 \\
Acealdehyde & 1.5 \\
Acetic acid & 6 \\
$\alpha$-Pinene & 18 \\
Limonene & 38 \\
Skatol & 0.0056 \\
Butanethiol & 0.0028 \\
\hline
\end{tabular}

類があり目的や許された時間・コストなどにより選択しま す。一般的には空気中を漂う香気成分を捕集するへッドス ペース捕集法, 対象物中の香気成分を有機溶媒や捕集剂等 を用いて抽出する方法, または蒸留して揮発成分を得る方 法, さらにはこれら手法を適宜組み合わせた手法が用いら れます。詳細については紙面の関係から別の機会に譲るこ ととします.

GC/MSで成分分析を行うと生花の香りでは数十種類と いった比較的単純な組成であることがあります。一方で コーヒーや調理食品などの香りは組成が多く, 数百から千 にも及3゙香気成分で成り立っているとの報告があります7). 上述したように個々の成分は個々に㫐い閾值を持っており, 極めて低い㫐い閾值を持つ成分は痕跡量しか存在しなくて も香り全体に影響を及ぼす場合があります。したがって, ある成分の量が多いこととその成分が全体の香りにとって 重要であるかどうかは実はあまり関係がありません．この ような痕跡量の重要な成分を検出し同定できるかどうかは 質量分析装置の感度が勝負となります.

さて，表題に掲げました「香りを分析する」とはどうい うことでしょうか.「香り」とはわれわれヒトが感じる感 覚により引き起こされるものであり, 感じて初めて「香り」 と言えます.したがって「香りを分析する」とはヒトがそ の香りをどのように感じるかを精査しなければならないと いうことになります。質量分析装置を用いた香気成分の定 性・定量分析を行うだけでなく, 香りの質や強度を評価す
る「官能評価」のアプローチが非常に重要となります，香 料会社では香りがどのような「要素」から成り立っている かを調べます，例えば，「甘い」「酸っぱい」「フルーツの ような」「薬品的」「焦げ臭」などの香りの要素の有無とそ れぞれの要素の強弱などです。このような評価も含めて 「香りを分析する」ということになります。またこれとは 別に，個々人に主観的な「好き・嫌い」があります．同じ 香りを嗅いでもそれを受け入れられるかどうかは個々人の 嗜好によりますので香りの開発においては非常に難しい課 題となっています.

\section{4. ガスクロマトグラフ質量分析計（GC-MS）を 用いた香気成分分析}

さて，香気成分分析を行うには一般的にGC装置を用い ます。上述しましたように香気成分は，1）分子量が 300 程 度までで適度な揮発性を有すること，2）多くは脂溶性（油 溶性）であること，3）数百の成分からなる混合物であるこ と, この三つの特徴から分離段を GC とすることが最も効 果的です。逆にGC装置とはこのような特徵を持つ成分の 分析に適していると言えます.

\section{1 ガスクロマトグラフィー（GC）}

ガスクロマトグラフィー（気-液クロマトグラフィー）は 1952年James と Martinにより創始された ${ }^{8)}$ と言われていま す。その後間もなく Parkin-Elmer社やCarlo Erba社, 日本 の(株)島津製作所によりGC装置が市販されました。弊社 でも1959年にはすでに(株)島津製作所製GC-1A が導入さ れて（写真1）おり ${ }^{9} ， 1960$ 年に $l$-mentholの異性化反応に おける各種異性体生成比を GC装置にて確認したと報告し ています ${ }^{10)}$. 当時の分離カラムは内径数 $\mathrm{mm}$, 長さ $4 \mathrm{~m}$ 程 度の充填カラムが主流でありました。これを用いた香気成 分の分析研究は大学研究機関, 香料会社などで一気に花開 きました。

その後Golayカラムと呼ばれる内径の細い開管キャピラ リーカラムの登場を経て, 1980年代以降光ファイバーの 


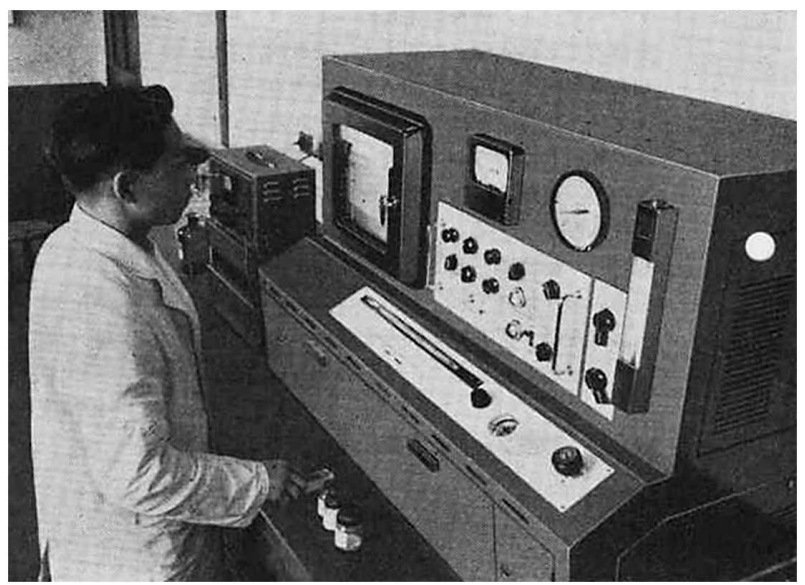

写真 1. 高砂香料工業(株)に導入されたガスクロマトグラフ GC-1A（1959年).

製造技術を利用したフューズドシリカキャピラリーカラム が登場しました。これによりカラム内径の細径化が進み メートル当たり 5,000 段を超える理論段数により高分離ま たは分析時間を短縮できるなど大きな恩恵がありました。 また, カラム内面の不活性化や cross-link と呼ばれる化学 結合による液相の架橋処理技術が進み安定したデータを取 得できるようになりました。

GCカラムの内面コーティングに用いられる液相は分析対 象物の極性に合わせ無極性の polydimethylsiloxane (PDMS) から強極性の polyethylene glycol (WAX) やそのテレフタル 酸誘導体などまでさまざまな極性度の液相を持つカラムが 販売されています. 香気成分分析では内径 $0.25 \mathrm{~mm}$ 程度, 長さ30 60 m, 液相は無極性の $100 \%$-PDMS や微極性の 5\%-phenyl/95\%-PDMS または強極性WAXのカラムを単独 または併用します。このような条件下での香料の GC分析 はおよそ1時間程度を要します. Mondelloらはメートル当 たり20,000段にも及ぶ非常に内径の細い $0.05 \mathrm{~mm}$ のキャピ ラリーカラムを用いて精油成分の GC 分析を 90 秒で完了し, 通常の GC 分析と比較すると 30 倍以上高速化を達成したと 報告しています ${ }^{11)}$.

香気成分分析で用いられる GCの検出器にもさまざまな 種類があります. FID (水素炎イオン化検出器), TCD (熱 電導度検出器), FPD (炎光光度検出器), NPD (窒素リン 検出器), MS (質量分析計) などが使われます，FIDは多 くの有機化合物を検出できるため汎用的用途で用いられま す。しかし, 水や高度に酸化された化合物は検出できませ ん. また検出器応答の直線性が広い濃度域で確保されるの でピークエリア值の比較でもおよその量の論議をすること ができます，TCDは水を検出できるのが特徴です，香料に 使用される溶剤である水やアルコール類の確認をする場合 などに使用されます，FPD，NPDは香気成分として一般に 匂い閾值が非常に低いことからごく微量でも香気全体に影 響を与える含窒素, 含硫黄化合物を高感度に検出できま す。このような香質に大きな影響を与える化合物群を選択 的に検出できることは香気成分分析を実施するうえで非常 に有用です．香気成分の分析ではさまざまな GCの検出器

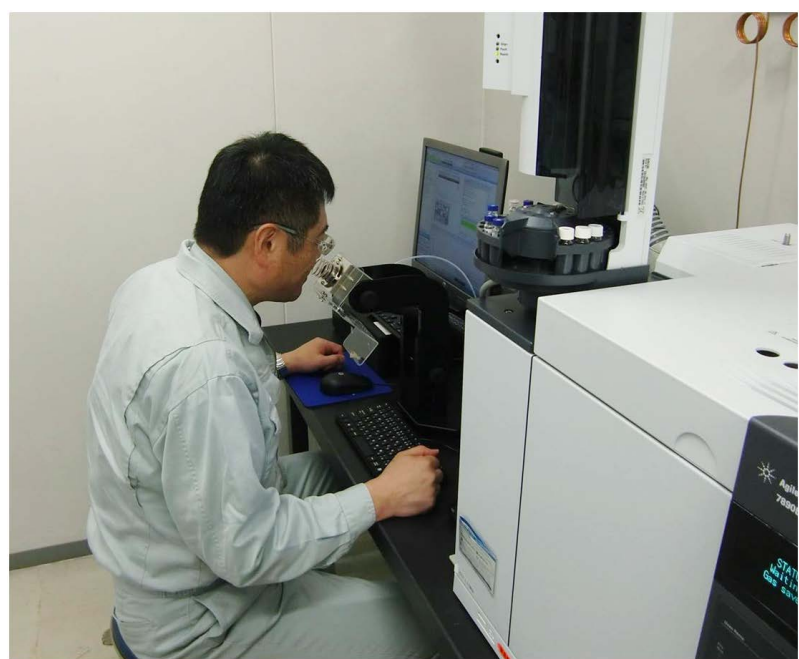

写真2. GC-O実験の様子 (筆者).

を用いて分析を行いますが，上述したこれらの検出器で得 られる情報は「保持時間（保持指標）」と「強度」のみで あり，分離された個々のピークがどのような化合物なのか 同定するための十分な情報は得られません．多くの成分を 含有する香気成分分析にてそれぞれのピークを成分同定す るためには質量分析計を用いる必要があります。一方で, 香気成分分析に特有な分析法として「ヒトの鼻」を検出器 として用いる GC-Olfactometry（GC-O）という方法があ ります.GC分離カラムの終端をスプリッターを介して分 岐させ，一方をFIDなどの装置検出器へ接続しもう一方を GC装置の外部に導き，キャリヤーガスとともに順次溶出 する成分を自身の鼻で嗅ぐというものです (写真2)、GC 分析時間中，集中して嗅ぎ，溶出してきた香質の情報を記 録し続けます．非常に労力のいる作業ですが，個々の成分 の香質を確認したり, 分析機器の検出器では検出が困難な 成分を自身の鼻で確認するなど，香料会社での研究開発で は必須の装置となっています。

\section{2 電子イオン化（EI）法による質量分析}

質量分析計は，1）試料導入部，2）イオン化部，3）質量 分離部，4）検出部からなり，それぞれの種類の組み合わせ 
によりさまざまな質量分析計が上市されています。弊社では 今から約 50 年前となる 1968 年に(株) 日立製作所製 RMU6L型単収束型質量分析計の導入 (写真3) を皮切りに, RMU-6M型, M-80型, M-80B型, M-2000A型の単収束な

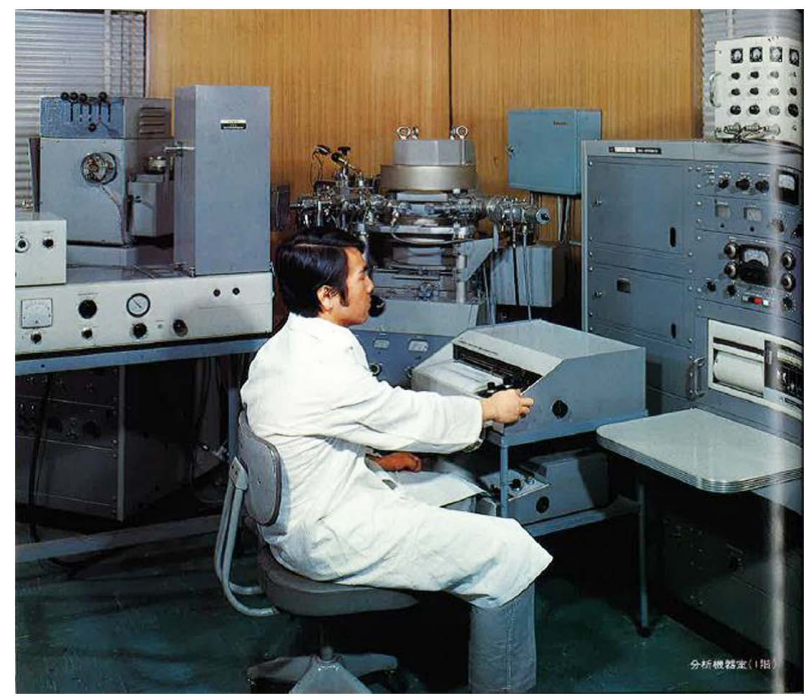

写真3. 高砂香料工業(株)の RMU-6 L ガスクロマトグラフ質 量分析計（1970年頃).
いし二重収束型質量分析計 ${ }^{12)}$ を順次導入してきました。こ れら装置はすべて分離段にGCを接続しており GC-MS 装置 として香気成分分析を実施していました。1970年代にはこ れら装置を用いた分析報告が見られます13),14)。また，直 接導入プローブを用いて天然物または合成香料や化学材料 のEIおよびCI，SIMSイオン化によるマススペクトル測定 も実施していました。80年代ぐらいまでは二重収束型の 質量分析計で香気成分分析を行うのは比較的一般的であっ たと思われますが，装置は非常に大きいため設置には6畳 ぐらいのスペースを要しました。

現在香気成分分析で用いられる一般的なデスクトップ型 GC-MS装置は1980年ごろより市場に出始めました。その 構成は，1）GC装置とのインターフェイス，2）電子イオン 化（EI）法，3）シングル四重極，4）エレクトロンマルチ プライヤー，というのが標準的で現在でもこの構成が主流 となっており，弊社でもこの構成の装置を多く導入してき ました. EI法は試料に熱電子を当ててイオン化する方法で, エネルギーが大きいことから生成した分子イオンから結合 開裂してフラグメントイオンを与えます．香気成分物質で はEI法により得られたマススペクトルからさまざまなフラ グメントイオンが観測されます。図 2 にいくつの香気成 分物質の EI マススペクトルを示しました。イオン化エネ
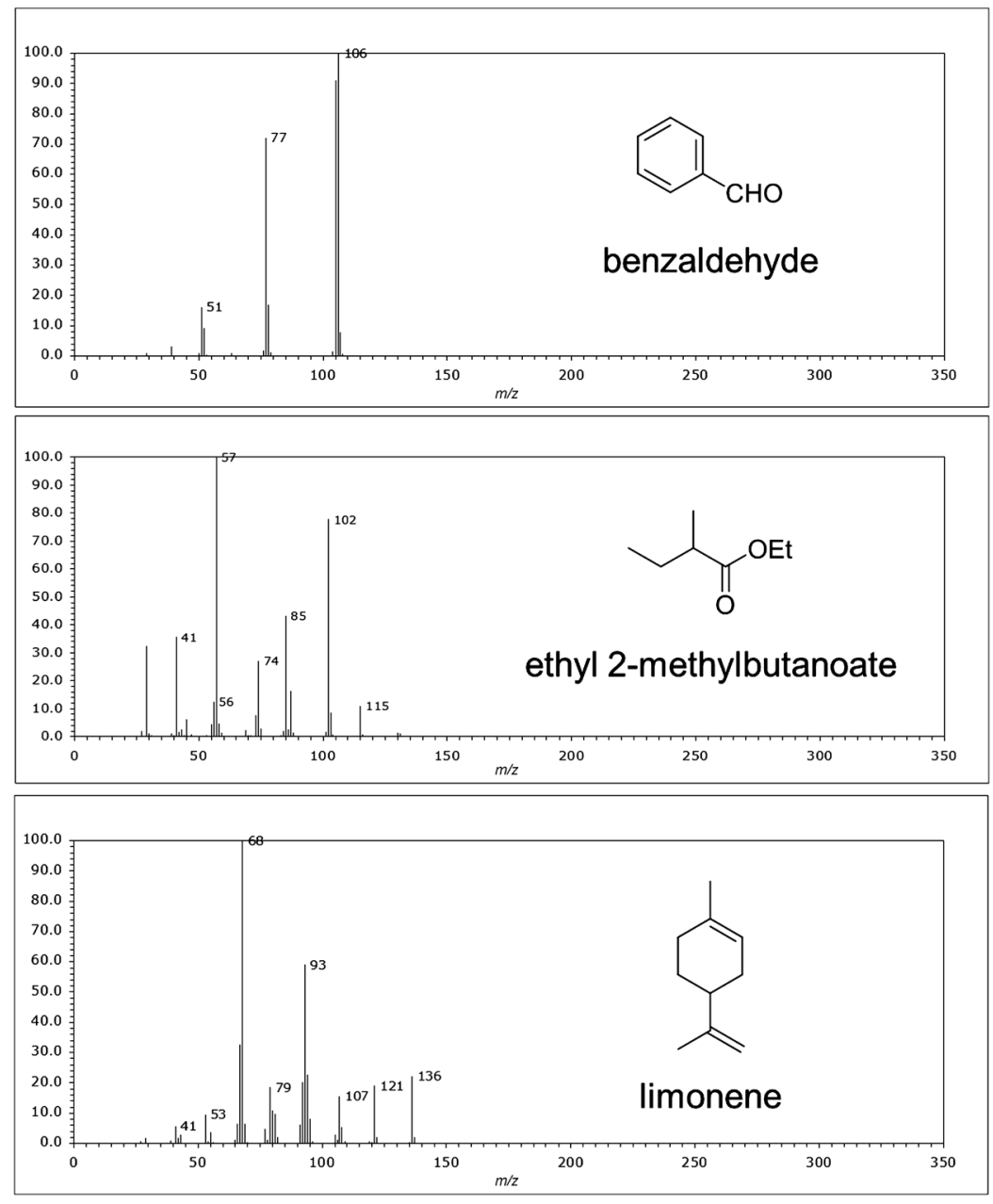

図2. 香気成分物質のマススペクトル例. 


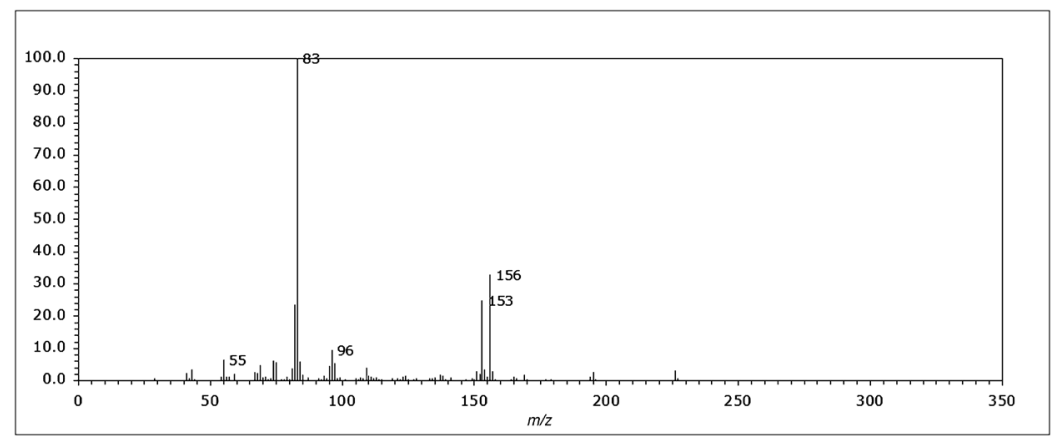

図3.フレグランス製品に頻出する香料原料.

ルギーなどの測定条件が近しければ装置メーカー・機種を 問わず観測されるフラグメントパターン（イオン $(\mathrm{m} / \mathrm{z})$ と その強度）は化合物ごとにほぼ同一となることが EI法の最 大の特徴です。このためEIマススペクトルは化合物の「指 紋」として扱うことができます。この特性は香気成分分析 で化合物を同定するという作業に対して非常にマッチして おり，他の手法の追随を許さない理由の一つです.

\section{3 データ解析}

GC-MS 装置でデータを取得したあとはそのデータの解 析を行います。香気成分分析の場合，ノンターゲット分析 であることが多く, 数百にも及ぶ検出ピークすべてを同定 にかかります。これは上述したように, 含有量が少なくて も匂い閾值が低い成分は香りの質に大きな影響を与えるた めです，重要な低閾值成分を見逃さない，またはGC-Oで ヒトの鼻にて確認された香りをマススペクトルデータで裏 付けを取ることが求められたりします。実際の作業はトー タルイオンカレント（TIC）クロマトグラムの任意の保持 時間のマススペクトルを切り出し, 別に準備されたマスス ペクトルライブラリーとの照合を行い, 一致度の高いスペ クトルを候補としてピックアップします。香気成分で頻繁 に検出されるテルペン類, 脂肪族類はスペクトルパターン が非常に似通ったものが多くあり誤同定してしまう恐れが あります。そのため, ライブラリーにはGC保持時間（ま たは保持指標：retention index）の情報を持たせます。香気 成分分析においてはスペクトル一致度と GCの保持情報の 2つを判断して同定します。場合によっては強極性のWAX 系カラムでの分析と微極性の 5\%-phenyl系のカラムの両方 で分析し，それぞれの同定結果を総合します。これにより ピークオーバーラップにより拾いきれなかった成分や, 一 方のカラム液相と相性の良くない成分を他方の液相のカラ ムで検出するなど両者の情報を補完します。

市販のマスライブラリーには収載スペクトル数が数十万 にも及ぶNIST やWileyが有名で GC-MS 装置の制御 PCにも バンドルされることがあります。また，香気成分分析に特 化したスペクトルライブラリーとして Adamsの精油成分に 関するマスライブラリーやMondelloによるフレーバー／ フレグランス, 合成香料成分のマスライブラリー ${ }^{15)}$,16) な どが市販されています。しかし実際にはこれらのマスライ ブラリ一集を入手しても同定できない成分が多くあるた
め，香料会社をはじめさまざまな研究機関で独自にマスラ イブラリーを編纂し，それを活用して日常の研究開発業務 にあたっています。したがってこれら独自のマスライブラ リーは各々の研究機関にとって最重要知的財産の一つであ ると言うことができます。

弊社では1980年代に利用していた日立製作所 M-80/002B ガスクロマトグラフ質量分析システムにて, オートサンプ ラーによる測定からデータ処理システムによるピーク検出, 独自に編纂したマスライブラリーを用いたマススペクトル 検索，およびその結果出力までを全自動化したシステムを構 築しました。その後，1990年に導入したM-2000A/D-2500 システムでは日立製作所と弊社にて「PC-LANシステム」 を共同開発しました ${ }^{17)}$. 従来, 装置制御のコンピューター のみでデータ取得から処理まですべて行っていましたが, メモリ不足やシングルタスク処理のため日常作業に大きな 不便を生じていました．PC-LAN システムでは質量分析計 の制御コンピューターと複数の PCをネットワークで接続 し，取得したデータをPCへ転送してスペクトル検索を実 施できる環境を提供しました。これは当時 GC/MS分析に よる香気成分分析が普及し研究員からのニーズが大きく増 える中で作業効率に関して変革をもたらしました，すなわ ち, 制御コンピューター上で行う処理を大きく軽減させ, 多数の GC/MS データを複数の研究員がPCを利用し並行し て解析することに成功したのです.

最近ではGC-MS装置付属のデータ解析ソフトウェアの 機能向上と PCの性能向上によりこのようなマススペクト ルの差分処理や自動同定処理がスムーズに実施できるため, GC/MS データ取得後すぐにライブラリーサーチによる同 定結果が得られるようになっています。しかしまだ手放し で自動同定の結果を受け入れられるほどの正確性はなく, 分析者による結果の検証は必須となっています.

香気成分分析に携わる熟練の研究者は頻出する香気成分 のマススペクトルと保持時間はおよそ頭に入っています. そのため, PC画面上でマススペクトルを見た段階で成分 の予測ができ，その後マススペクトル検索を行ってその結 果をもって自身の予測が間違っていないことを確認すると いう流れで成分解析作業を行っています。例えば図 3 に示 したマススペクトルはフレグランス製品に多量に処方され ることのある成分でフレグランス香気成分分析に携わった 
ことのある研究員であれば多くの方が見覚えのあるマスス ペクトルだと思います18).

\section{5. その他の質量分析装置の利用}

近年質量分析装置の進化はとどまることを知りません． 香気成分分析や香料素材の分析において有用な質量分析装 置のいくつかを紹介します.

\subsection{GC $\times$ GC-TOF-MS}

10年前ぐらいにLECO 社から登場したTOF-MSである Pegasus 4Dシリーズはユニットマス分解能ではあるものの 毎秒500スペクトルと高速なデータ取得が可能です。また 最近Dani社からは毎秒 1,000 スペクトルの取得が可能な高 速なTOF-MSが上市されました。これほどまでに高速な データ取り込みが実施できると超高速 GCの検出器とし て, または超高分離な $\mathrm{GC} \times \mathrm{GC}$ の検出器として，さらには GCカラムでのピーク分離を補完するデコンボリューショ ン処理が十分に機能します. 実際の GC $\times$ GCデータ処理 においては通常の GC/MS データに比べ非常に多くのピー クが検出され，また，データは保持時間に関してx軸とy 軸の二次元に展開されていることから, 網羅的かつ詳細に 成分同定するには相当の時間と根気を要します。ターゲッ ト分析であればその分離とモジュレーターでのピーク濃縮 や検出感度の優位さにより低濃度成分の検出が可能となり ます。また, 試料間の比較を目的とする際には各試料で検 出される多数の成分の量の情報を統計解析手法で処理して 表現することにより，試料間の相違を可視化して説明する 試み ${ }^{19)}$ が多くなされています。

\section{2 高分解能 GC-MS}

20 年ぐらい前は高分解能質量分析でミリマス測定を実 施するには二重収束型の質量分析計を利用する必要があり ました。その際にはイオンが通過するスリットを狭め，レ ンズ系を調整するなどさまざまな最適化が必要でした。最 近ではロックマスを導入しなくても分解能数万のデータが 安定的に得られるTOF-MS Orbitrap型）の装置が手に入るようになりました，天然物 の香気成分探索に扔いて，いまだに分子量 $300 に も$ 満たな い新規化合物が見いだされます。このような不明成分の構 造を明らかにする探索研究だけでなく, 合成香料の副生成 物の迅速な構造決定においても高分解能マススペクトルは 分子式の確定に必須の情報です. また, 分子イオンだけで なくフラグメントイオンも含めすべての $m / z$ が高分解能・ 高精度な值として得られることは部分構造の妥当性を評価 する際に大きな助けとなります。

最近では定量用途でこの高分解能質量分析計が利用され るようになってきました。一般に定量分析は三連四重極型 質量分析計の Multiple Reaction Monitoring (MRM) 測定で 選択性を確保するケースが多いようですが，高分解能質量 分析計では分解能数万という非常に高い分解能で元素組成 の異なるイオンの分離を行うことで選択性を確保します. MRM測定でコリジョンの後に十分な強度のイオンが得ら れない場合やプロダクトイオンの選択性が良くない場合に
非常に有効な手段と言えます。

\section{3 加速器質量分析}

最後に特殊な例を一つ紹介します．質量分析手法の一種 である加速器質量分析法は年代測定を実施する際に利用さ れることで知られています，炭素の放射性同位体である ${ }^{14} \mathrm{C}$ と安定同位体の ${ }^{13} \mathrm{C},{ }^{12} \mathrm{C}$ の三者の比率を求めることによ り年代がわかります。本手法の原理は，動植物の代謝が止 まった組織が炭素を取り込まなくなると，体内に残った放 射性同位体 ${ }^{14} \mathrm{C}$ はその 5,730 年という半減期にしたがって 減少していくということに基づきます。

加速器質量分析法による年代測定に供した試料は「伽羅」 香木でした．江戸時代の長崎を舞台にした「一木四銘香」 として知られる次のような伝説が背景でした．江戸時代初 期, 長崎に輸入された最高級伽羅香木の所有をめぐり, 肥 後細川家, 加賀前田家, 仙台伊達家の家臣の間で争いとな り殺傷事件にまで発展しました。これを重く見てこの伽羅 香木を四分割し一つを天皇に献上し勅命を請い，残りを各 家で分け，それぞれ後水尾天皇勅命「藤袴（または蘭）」 （宮中），「初音」(加賀前田家)，「白菊」(肥後細川家)，「柴 舟」(仙台伊達家) と附銘されたという伝説があります。 もともと一つの伽羅香木を四つに分けてそれぞれに名銘し たことから「一木四銘香」と呼ばれています．香木はその 香りを聞いて（聞香され）歌が詠まれることがありますが, これら四つの香木も下のように読まれています。

【藤袴】ふじばかまならぬ匂ひもなかりけり 花は千種の いろまさるとも

【初音】聞くたびにめづらしければほととぎす いつも初 ねのここちこそすれ

【白菊】たぐありと誰かはいひし咲き匂ふ 秋より後のし らきくのはな

【柴舟】世の中にうきを身につむ柴舟や なかぬさきより まづこがるらん

弊社では高砂コレクションとして水戸徳川家由来の「一 木四銘香」を所有しており，これら銘香木のごく微量を科 学分析に供することが許されたことから，四銘香それぞれ をGC-MSによる香気成分分析, GC-Oによる成分香気確 認，および年代測定を実施するに至りました ${ }^{20)}$ 。加速器 質量分析計による年代測定は福島県白河市にある(株)加速 器研究所白河分析センター ${ }^{21)} に お$ 願いしました。現地に 赴くと体育館のような大きな建屋にこれまでに見たことも ないほど巨大な質量分析計が設置してあり，イオンが通る パスは $20 \mathrm{~m}$ もろうかというほどでした。

年代測定の結果は下記のようでした。十分な試料量が確 保できる場合, 本測定法の誤差は土 30 年程度といわれてい ます。このときに年代測定のために許された試料量は僅か $5 \mathrm{mg}$ であり測定を実施できる最低限の量でした。そのた め, この結果は精度の面で若干の問題は有していると考元 られます。この逸話の真偽のほどはわかりませんが，四銘 香いずれも 300 年から 450 年程度前のものでありこれらが 


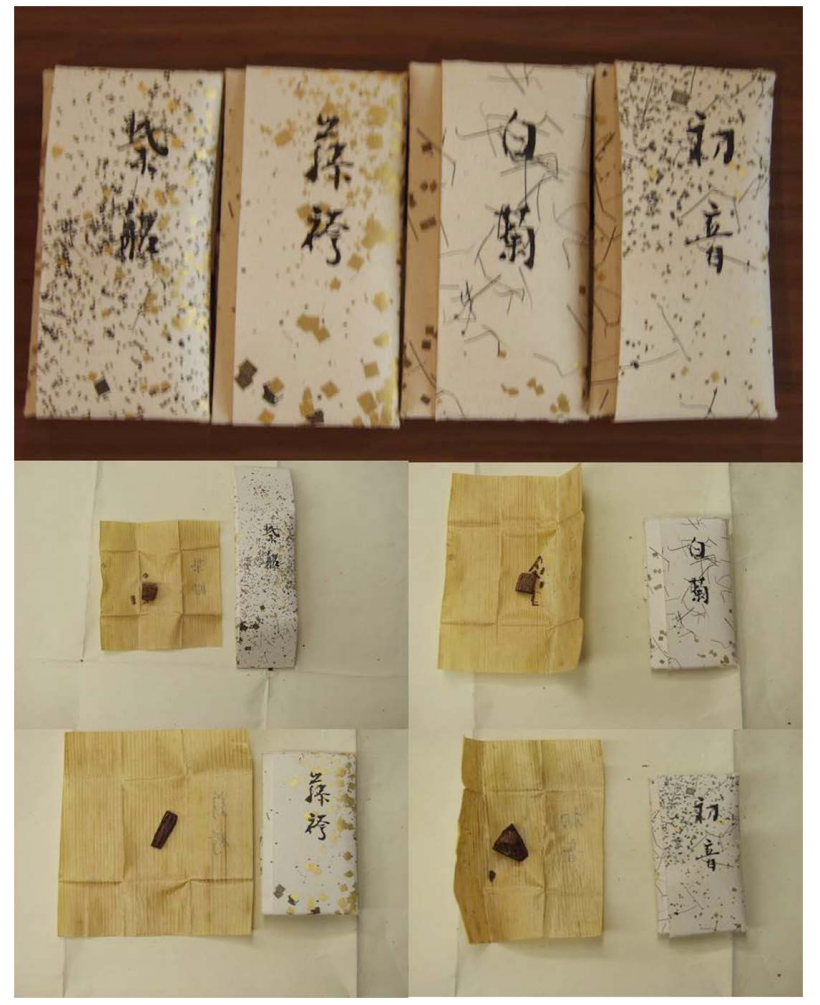

写真4. 一木四銘香.

ほぼ同年代のものであると考えられます.

\section{【藤袴】 1700 年 【初音】 1610 年 \\ 【白菊】1550年【柴舟】1640年}

\section{6. おわりに}

GC や質量分析法が登場する以前の調香師は対象物を自 身の鼻 (検出器) で官能 (分析) し含まれている成分の香質 を見極めて調合していました。これら装置登場以降は容易 に，迅速に，正確に香気成分分析を行うことができるよう になりました。これはその当時, 調香という作業が革命的 に変化したことを意味します。香気成分分析において質量 分析手法が担う役割の重要さは将来も変わらないでしょう. 一方で今後質量分析計の高感度化・高精度化と相まって, センサー技術, マンマシンインターフェイス, IoT技術, マシンラーニングなどの分野の技術がますます進歩し, こ れら技術と質量分析手法が融合していくと思われます。そ の時には, 質量分析手法特に GC/MSは「マススペクトル」 など意識せずとも成分分析の結果を高い確度で提供し，さ らに有用な情報を付加してくれるシステムに変貌していく
ものと大いに期待しています。 また香りというものは日本 古来より親しまれ，一つの文化を形成しています。香りの 分析に携わるということは単に理化学的手法を存分に駆使 するだけでなく，歴史文化の一端を担っているということ を自負しつつ日々の研究活動に勤しんでいきたいと思って おります。

謝 辞 最後にこのような投稿の機会を与えてくださっ た日本質量分析学会誌編集委員の先生方および導入より 50 年間続く弊社の質量分析技術を脈々と受け継いでこら れた歴代の研究員のみなさまに感謝し厚く御礼申し上げ, 本稿を結びたいと存じます。

\section{文献}

1）江村 誠, 蟹沢恒好, 日本味と匂学会誌, 9, 19 (2002).

2) M. Emura, Y. Yaguchi, A. Nakahashi, D. Sugimoto, N. Miura, and K. Monde, J. Agric. Food Chem., 57, 9909 (2009).

3) K. Monde, A. Nakahashi, N. Miura, Y. Yaguchi, D. Sugimoto, and M. Emura, CHIRALITY, 21, E110 (2009).

4）永田好男, 竹内教文, 日環也所報, 17, 77 (1990).

5）岡島佐知子, 中山優子, 菅原俊二, 香料, 272, 75 (2016).

6）中山優子, 丸山賢次, 矢口善博, 岡島佐知子, 今井瑠里 子，菅原俊二，第 61 回香料・テルペンおよび精油化学に関 する討論会要旨集， 61, 147 (2017).

7) L. Mondello, A. Casilli, P. Q. Tranchida, P. Dugo, R. Costa, S. Festa, and G. Dugo, J. Sep. Sci., 27, 442 (2004).

8）代島茂樹，保母敏行，前田恒昭，役に立つガスクロ分析, みみずく舎（2010）。

9）高砂香料時報, 4,18 (1959).

10）吉田利男，第 4 回香料・テルペンおよび精油化学に関する 討論会要旨集, 4, 15 (1960).

11） L. Mondello, R. Shellie, A. Casilli, P. Q. Tranchida, P. Marriott, and G. Dugo, J. Sep. Sci., 27, 699 (2004).

12）高砂香料 50 年史編集委員会, 高砂香料 50 年史（1973）.

13） R. Hattori, S. Muraki, and T. Yoshida, Agric. Biol. Chem., 42, 1351 (1978).

14) T. Toyoda, S. Muraki, and T. Yoshida, Agric. Biol. Chem., 42, 1901 (1978)

15) R. P. Adams, Identification of Essential Oil Components by Gas Chromatography/Mass Spectrometry, 4th Edition, Allured Publishing Corp., Illinois (2007).

16) L. Mondello, Mass Spectra of Flavors and Fragrances of Natural and Synthetic Compounds, 3rd Edition, John Wiley \& Sons, Inc., New York (2016).

17）野原 功，第10回日立MSユーザーズ・カンファレンス要 旨集, A-1 (1990).

18）答 : methyl dihydrojasmonate

19) T. Inui, F. Tsuchiya, M. Ishimaru, K. Oka, and H. Komura, J. Agric. Food Chem., 61, 4758 (2013).

20）矢口善博, 江村 誠, 高砂香料時報, 146, 10 (2003).

21）株式会社加速器研究所ホームページ：http://www.iaa-ams. co.jp/ 